\title{
Introducing Municipal Bond Markets in Malaysia : An Assessment of Present Market Characteristics
}

\author{
MUKARAMAH HARUN \\ TING DING HOOI \\ HUSSIN ABDULLAH \\ Faculty of Economics \\ Universiti Utara Malaysia
}

\begin{abstract}
In developed countries, urban growth has multiplied the demand for investment in basic infrastructure services such as water supply, waste removal, roads and mass transportation. At the same time, decentralization strategies have shifted the responsibility for much of these investments to the local governments. This decentralized investment requires the development of decentralized capital financing. No longer can a central government pay for local investment by raising national taxes or borrowings on international markets and using the funds simply to construct projects at the local level. The introduction of municipal bonds is one of the alternative source of funds to finance the escalating costs of financing local governments. This paper discusses the conditions underlying the development of municipal credit markets, which Malaysia can use to provide a vehicle to narrow the local government's resource gap through debt funding.
\end{abstract}

Keywords; Municipal bonds, bonds market, capital financing

\begin{abstract}
ABSTRAK
Pertumbuhan perbandaran yang pesat telah meningkatkan permintaan ke atas pelaburan dalam perkhidmatan infrastruktur asas seperti pembekalan air, pembentungan, jalan raya dan pengangkutan. Pada masa yang sama, strategi desentralisasi telah memindahkan sebahagian besar tanggungjawab pelaburan kepada kerajaan tempatan. Desentralisasi tanggungjawab pelaburan ini perlu sealiran dengan pembangunan dalam desentralisasi pembiayaan modal supaya tiada lagi pergantungan kepada kerajaan pusat bagi membiayai pelaburan tempatan dengan meningkatkan cukai negara atau mendapatkan pinjaman di pasaran antarabangsa. Pengenalan bon perbandaran merupakan salah satu sumber dana alternatif untuk membiayai kos yang semakin meningkat bagi kerajaan tempatan. Kertas ini membincangkan keadaan pasaran yang diperlukan bagi pembangunan pasaran kredit perbandaran di mana ia dapat menawarkan satu alat yang berupaya untuk mengurangkan jurang sumber kerajaan tempatan melalui pembiayaan hutang.
\end{abstract}

Kata kunci: Bon perbandaran, pasaran bon, pembiayaan modal. 


\section{INTRODUCTION}

Municipal credit systems can be an important element of development strategy because they stand at the crossroads of three of the most basic trends affecting the developing world. Rapid urbanization has magnified the need for infrastructure investments. At the same time as urban investment needs are mounting, decentralization initiatives are transferring greater responsibility for planning and financing investment projects to local and state governments. Fiscal adjustments are impelling all levels of government to try and reduce their budget deficits. One favorite deficit reduction instrument has been to cut back government subsidies in the financing of infrastructure projects. Studies in different parts of the world have found that capital investment support by the government was reduced tremendously compared to any other element of spending during periods of tight budget constraints. To sustain investment levels in the face of reductions in the central-government capital grants, local authorities have had to make greater use of borrowings as a way to finance their capital projects.

Developing countries have been exploring many strategies to help the financing burden of the federal and the state governments. One new strategies explored and sometimes used is to let the local governments seek their own sources of financing. For Malaysia, the idea for the introduction of a municipal credit system should actively be looked into. For this purpose the most important element is to evaluate the underlying conditions or characteristics of the present financial market where borrowers and lenders would meet. To what extent does there exist a 'market' for sub-sovereign obligations and how should potential borrowers access it? This paper attempts to see the present conditions of the Malaysian bond market in order to see the possibility of introducing municipal bonds to finance urban infrastructure. The paper is presented within a framework suggested by the key strengths of the U.S. municipal bond market, often used as a model for market development in developing economies.

\section{LITERATURE REVIEW}

The significance of municipal bonds as a source of fund is undeniable. There are many developed countries that have been using this instrument in obtaining additional funds for the development of the municipalities. It is used as a vehicle towards sustaining the growing needs of the population in terms of infrastructure services. With rapid urbanization the demand for the municipal bonds has also intensified. This can be seen in the utilization of the security and bond markets in most developed countries.

In view of the growing needs and also the advantages of using municipal bonds in a country, most governments have blended together the private and public entities in searching for a new agenda in providing and issuing bonds. As the importance of debt management increases, the dependence on debt intermediaries has grown to a scandalous point and requires action (Miller, 1993). In connecting the investors with the borrowers, financial intermediaries play a role in finding new investors as well getting the existing investors to provide more funds. According to Hildreth (1993), securities issued by the state and local governments are to obtain financing for public projects or activities. Whereas the revenue bonds may serve as a strategic tool for municipals facing fiscal strains or limits (Sharp, 1986). This blending between the private and public entities would benefit both parties to some extent.

Most of the countries having a deficit financing require a way to source out their finance investment. According to Miller (1993), large U.S. budget deficits, compounding large amounts of debts held by corporations, state and local governments and households strain the financial system's supply of capital. According to Hildreth (1993), there are two distinctive qualities in municipal bonds that are the tax exempt status and the absence of restrictive federal regulations. A study by Fortune (1992) calculated that the magnitude of instability, equity and financial efficiency in 1990 and concluded that tax exemptions cost the U.S. treasury USD22 billion to USD24 billion in which each state 
and local governments reduced their interest payments by USD16.9 billion to USD18.5 billion.

While designing the bond structure, the issuer has an option in how and when it will sell bonds (Hildreth, 1993). Hence this will enable the local governments to improve their debt structure according to their own time and pace. There has been an extensive study on the competitive bidding or negotiated sale that leads to lower borrowing costs for municipal debt issuers (Jun \& Brucato, 2003). There is also the need for a clear priority schedule on the part of the government financial managers (Miller, 1993). Thus it will lead to a win-win situation where the government would be able to use the additional funds in generating more projects for the development of the nation while the private sector would gain in terms of the values accrued upon maturity.

Furthermore, creative debt instruments will also help the issuers take advantage of changing the market demands (Hildreth, 1993). According to Hildreth (1993), one of the borrower's goals is to be able to obtain the lowest costs of capital over the desired repayment schedule. The introduction of the municipal bonds will enable this situation. According to this researcher, the debt offerings are timed to meet market opportunities and not just the local financing agenda. Bland (1985) shows that up to a certain point, the more experienced a municipality is with the debt financing, the more likely it is that it will generate interest rates savings. Cook (1982) reaffirms that the state and local governments benefit from more competition for their bonds because when the demand for an issuer's securities increase, the issuer's cost of borrowing declines.

Therefore the benefits of the issuance of municipal bonds in a country and especially towards the sourcing of additional funds have been known both to the public and the private entity. According to Hildreth (1993), the incentives towards debt issuance are based on the needs for funds to secure physical assets that will enhance public services as well as advancing the political agendas and exploiting capital market opportunities. According to Cuciti (1991), public investments have a positive influence on private pro- ductivity, hence leading to the growing body of research in this area. Furthermore, a study by Ziebell \& Rivers (1992) on 411 cities found that small municipalities are less likely than larger ones to seek bond ratings. This further adds to the fertile area of this research in developing countries such as Malaysia.

\section{METHODOLOGY}

This study is exploratory and descriptive in nature, to assess the feasibility and practicality of introducing the municipal bonds into the Malaysian market as a source of funds for the municipalities. The assessment of the municipal bond market will be done based on the framework for assessing municipal bond market development as in Figure 1.

\section{Overview of the U.S. Municipal Bond Market as a Model for Development}

The U.S. municipal bond market is by far the largest and most active market in the world. Using the U.S. market as a model, there are a number of basic market strengths that have been identified as necessary to attract issuers and investors in a sustainable fashion. Many researchers have studied these strengths, as well as the ways in which they have been achieved in the U.S. market. The summary of the strengths are shown in Figure 1.

\section{A Preview of Local Governmental Entities as Borrowers}

Local government debt is the obligation of a local government or of the projects sponsored by the local government, including projects involving the private sector through subsidies, partnerships and concessions. An analysis of local government debt reveals many elements in common with other borrowing entities such as public utilities and private firms. However, there are some special features that are distinctive as a result of the power, structure and operations of the local governments. Local governments typically have certain powers over the local market for services that approach 


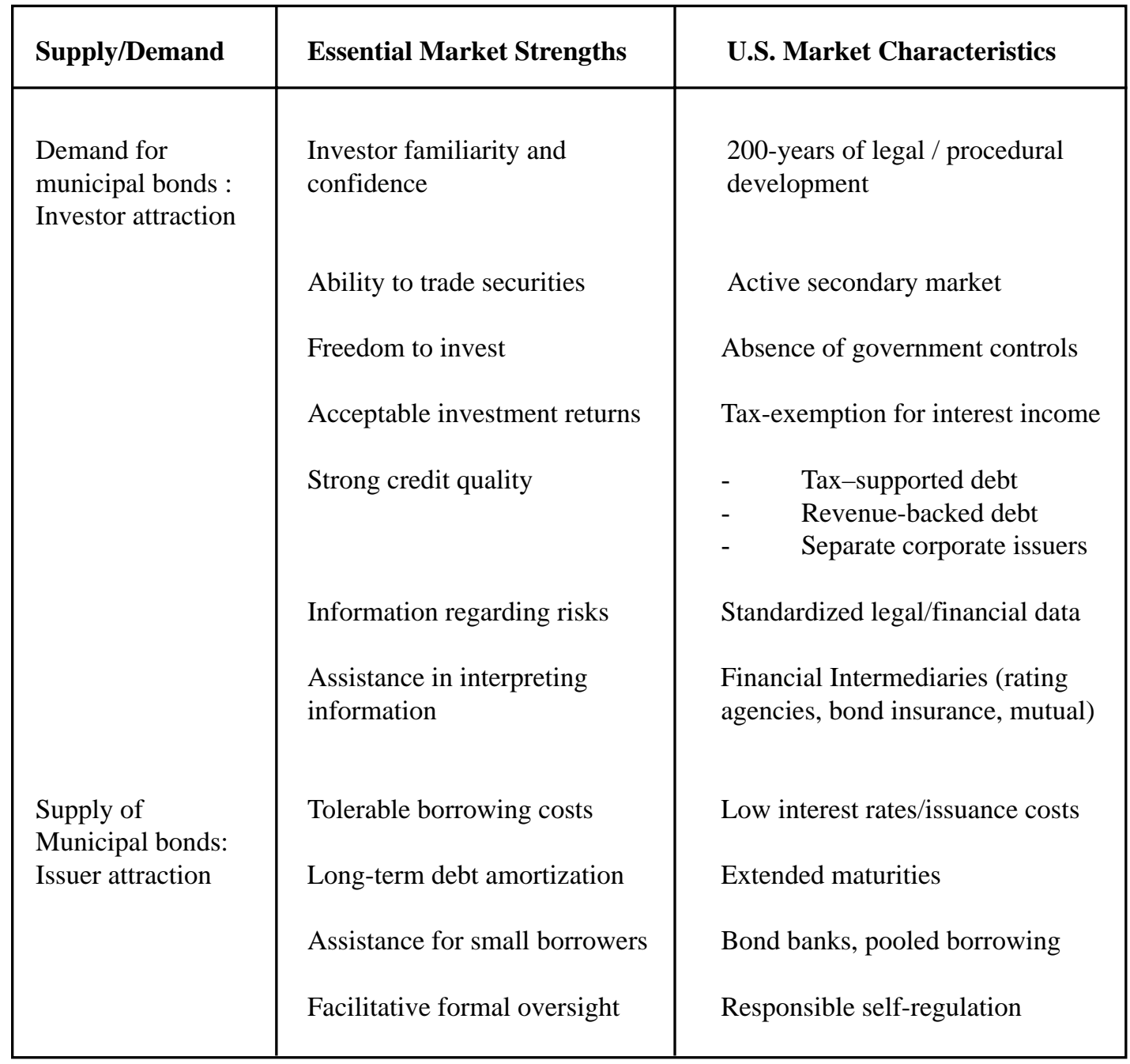

\section{Figure 1}

Framework for Assessing Municipal Bond Market Development

monopoly status and that may be enforced by regulation (Petersen \& Crihfield, 2000).

In most countries, local governments already have access to credit facilities which are available through government sponsored lending programs and bank lending. These funds however may be restricted to the development of local amenities and the provision of welfare to the public. The challenge is to expand the "marketbased' funding pool for local governments by tapping private individual and institutional savings.

\section{Malaysia's Local Government}

There are a total of ninety-nine local governments in Peninsular Malaysia comprising four city councils, nineteen municipal councils and seventy-six district councils. All of the local governments are subordinates to the respective state governments and formed as well as regulated by the respective state legislations. According to the Local Government Act of 1976, the major function of the local governments is to provide public goods and services to cater for 
the specific needs of the localities. The mandatory functions include all critical functions such as refuse collection, maintenance of minor drainage, sewerage treatment, road maintenance, street lighting and public health. Meanwhile discretionary functions include all development functions such as providing amenities, recreational parks, housing and commercial activities, markets, sports facilities and community centers (Fatimah Wati Ibrahim \& Mohd Faisol Md. Salleh, 2002) .

Table 1 shows that for most of the years under study, total revenue of local authorities was mainly contributed by their own sources particularly from assessment rates. The contribution of federal and state grants to total revenue of the local authorities is declining, but the amount is still significant (at over RM1.6 billion in 2002). The overall balance shows an improvement from negative values for three consecutive years from 1998 to 2000 to a positive value, which amounted to RM575 million in 2001 and RM1.45 billion in 2002. Though operating and development costs have escalated, the increase in revenue has been in tandem with the increase in expenditure. However, the overall surplus could not have been achieved without federal and state grants. The deficit overall balance provides the necessary foundation for the introduction of a municipal bond market to help finance the deficits.

Table 1

Local Governments Consolidated Finance (RM million)

\begin{tabular}{|c|c|c|c|c|c|}
\hline & $\mathbf{1 9 9 8}$ & $\mathbf{1 9 9 9}$ & $\mathbf{2 0 0 0}$ & $\mathbf{2 0 0 1}^{\mathbf{1}}$ & $\mathbf{2 0 0 2}^{\mathbf{2}}$ \\
\hline Revenue & 3,343 & 3,535 & 3,410 & 5,528 & 5,277 \\
\hline Own sources & 2,586 & 2,769 & 2,815 & 2,318 & 3,638 \\
\hline State and federal grants & 721 & 721 & 529 & 3,210 & 1,639 \\
\hline Federal reimbursements & 45 & 45 & 66 & 0 & 0 \\
\hline Current expenditure & 2,256 & 2,573 & 2,415 & 2,777 & 3,151 \\
\hline Current surplus/deficit & 1,807 & 962 & 995 & 2,751 & 2,126 \\
\hline Net development expenditure & 1,428 & 1,262 & 1,098 & 2,176 & 3,576 \\
\hline Overall balance & -341 & -300 & -103 & 575 & 1,450 \\
\hline
\end{tabular}

Bank Negara Malaysia (2002). Annual Report

${ }^{1}$ Estimated actual

${ }^{2}$ Revised estimated 
Meanwhile, Table 2 shows the consolidated account for three selected local governments; Kuala Lumpur City Hall (KLCH), Municipal Council of Penang Island (MCPI) and Municipal Council of Petaling Jaya (MCPJ). The table indicates that these local governments generated sufficient revenue to finance their needs so that the issuance of municipal bonds was not relevant here.

Table 2

Management Accounts for Selected Local Governments (RM million)

\begin{tabular}{|l|c|c|c|c|c|}
\hline & Income & Expenditure & $\begin{array}{c}\text { Surplus/ } \\
\text { Deficit from } \\
\text { operation }\end{array}$ & $\begin{array}{c}\text { Development } \\
\text { Expenditure }\end{array}$ & $\begin{array}{c}\text { Surplus } \\
\text { /Deficit }\end{array}$ \\
\hline $\begin{array}{l}\text { Kuala Lumpur } \\
\text { City Hall (KLCH) }\end{array}$ & RM913.3 & RM562.3 & RM351 & RM332.6 & RM18.4 \\
\hline $\begin{array}{l}\text { Municipal Council } \\
\text { of Penang Island } \\
\text { (MCPI) }\end{array}$ & RM139.8 & RM88.1 & RM51.8 & RM30.2 & RM21.5 \\
\hline $\begin{array}{l}\text { Municipal Council } \\
\text { of Petaling Jaya } \\
\text { (MCPJ) }\end{array}$ & RM142.3 & RM118.2 & RM24.2 & RM24.2 & RM0 \\
\hline
\end{tabular}

- Source: Annual Reports for the respective municipals

' Figures in 1998; Kuala Lumpur City Hall (1998). Annual Report. KLCH

${ }^{2}$ Figures in 1995; Municipal Council of Penang Island (1995). Annual Report. MCPI

${ }^{3}$ Figures in 2000; Municipal Council of Petaling Jaya (2000). Annual Report. MCPJ

\section{The Malaysian Bond Market}

Looking at the early progress of the security market in Malaysia, the foundation of the market has been the equity market, with the private debt market emerging much later. Most national debt markets are dominated by the central government debt. The banking system, either government owned or privately owned, also has tended to dominate investments in the government bond market along with government-controlled agencies. Corporate debt has traditionally been financed through the banking system and there are relatively few corporate bond issuers in the debt market. Recently, however, corporate bonds have gained significant attention and progress in Malaysia.
The figures in Table 3 give a general idea of the relative role of the financial market in Malaysia. In particular, we can gauge the relative contribution of the debt market and bank borrowing as a source of funding for both the public and private sectors, in relation to the Gross Domestic Product (GDP).

As Table 3 shows, the GDP grew rapidly in the 1990s, from RM79.6 billion in 1990 to RM209.3 billion in 2000. Over the same period, the bond market grew more rapidly, from RM69.27 billion in 1990 to RM240.62 billion in 2000 , an average growth of 24.74 percent per annum. Total bonds outstanding as a percentage of GDP increased from 87.06 percent in 1990 to 114.95 percent in the year 2000 . 
Table 3

Funds Outstanding in the Capital Market

\begin{tabular}{|c|c|c|c|c|c|c|c|c|c|c|c|}
\hline \multirow[t]{2}{*}{ Year } & \multicolumn{2}{|c|}{$\begin{array}{c}\text { Public Sector } \\
\text { Debt }\end{array}$} & \multicolumn{2}{|c|}{$\begin{array}{c}\text { Private Sector } \\
\text { Debt }\end{array}$} & \multicolumn{2}{|c|}{ Total Debt } & \multicolumn{2}{|c|}{$\begin{array}{c}\text { Market } \\
\text { Capitalization }\end{array}$} & \multicolumn{2}{|c|}{ Bank Borrowing } & \multirow{2}{*}{$\begin{array}{c}\text { Real } \\
\text { GDP }\end{array}$} \\
\hline & RM bil. & $\begin{array}{l}\% \text { of } \\
\text { GDP }\end{array}$ & RM bil. & $\begin{array}{l}\% \text { of } \\
\text { GDP }\end{array}$ & RM bil. & $\begin{array}{l}\% \text { of } \\
\text { GDP }\end{array}$ & RM bil. & $\begin{array}{l}\% \text { of } \\
\text { GDP }\end{array}$ & RM bil. & $\begin{array}{l}\% \text { of } \\
\text { GDP }\end{array}$ & \\
\hline 1990 & 63.0 & 79.1 & 6.3 & 7.9 & 69.3 & 87.0 & 131.7 & 165.5 & 115.5 & 145.1 & 79.6 \\
\hline 1991 & 66.2 & 76.7 & 8.1 & 9.4 & 74.3 & 86.1 & 161.4 & 187.0 & 140.1 & 162.4 & 86.3 \\
\hline 1992 & 67.6 & 72.7 & 11.5 & 12.3 & 79.1 & 85.0 & 245.8 & 264.0 & 155.4 & 166.9 & 93.1 \\
\hline 1993 & 68.9 & 68.2 & 15.1 & 15.0 & 84.0 & 83.1 & 619.6 & 613.5 & 173.5 & 171.8 & 101.0 \\
\hline 1994 & 70.6 & 64.2 & 24.1 & 21.9 & 94.6 & 86.1 & 508.9 & 463.1 & 201.7 & 183.5 & 109.9 \\
\hline 1995 & 70.9 & 58.9 & 32.0 & 26.6 & 102.9 & 85.5 & 565.6 & 470.2 & 259.0 & 215.3 & 120.3 \\
\hline 1996 & 72.2 & 55.3 & 46.8 & 35.8 & 118.9 & 91.1 & 806.8 & 617.8 & 329.6 & 252.4 & 130.6 \\
\hline 1997 & 70.9 & 50.4 & 63.4 & 45.0 & 134.3 & 95.4 & 375.8 & 267.1 & 421.2 & 299.4 & 140.7 \\
\hline 1998 & 81.9 & 62.4 & 75.4 & 57.4 & 157.3 & 119.8 & 374.5 & 285.2 & 413.5 & 314.9 & 131.3 \\
\hline 1999 & 83.2 & 62.7 & 89.2 & 67.3 & 172.4 & 130.0 & 380.6 & 287.0 & 427.7 & 322.5 & 132.6 \\
\hline 2000 & 130.8 & 62.5 & 109.9 & 52.5 & 240.6 & 115.0 & 386.6 & 184.7 & 416.3 & 198.9 & 209.3 \\
\hline
\end{tabular}

Source: Bank Negara Malaysia, (1991), (1995), (2001). Annual Report

To compare funds raised in the debt market as against funds raised in the equity market, Table 3 also provides data on the equity market (market capitalization). This equity market has grown significantly from RM131.7 billion in 1990 or 165.45 percent of the GDP to RM386.6 billion or 184.71 percent of the GDP in the year 2000. Bank borrowing has also grown significantly from RM115.5 billion in 1990 or 145.1 percent of GDP to RM416.3 billion or 198.9 percent of GDP in 2000.

Table 3 shows the dominance of government borrowing in the debt market in the early 1990s and their decline towards the end of the decade. Government bonds outstanding as a percentage of total bonds declined from 90.96 percent in 1990 to 54.35 percent in the year 2000 
while in contrast, corporate bonds as a percentage of total bonds increased substantially from only 9.04 percent in 1990 to 45.65 percent in the year 2000. However, corporate bonds are still low relative to corporate equities, which account for 52.46 percent and 184.71 percent of the GDP respectively.

The Government and other national level government-owned corporations as well as private companies are the principal bond issuers. No local governments or local government-own enterprises however have issued bonds in Malaysia.

\section{General Requirements of a Municipal Bond Market}

The discussion below outlines some general requirements that need to be met for the establishment and effective functioning of a municipal bond market in Malaysia.

\section{Attracting a Demand for Municipal Bonds}

\section{Investor Familiarity and Confidence}

In Malaysia, investors have been familiar with the government bond market and in recent years, increasingly in the corporate bond market. Issuers have increasingly used the debt market to raise cheaper funds in addition to the traditional borrowings from banks. The issuers, however, are mainly the federal government and private corporations. No state or local governments have ever made any bond issue. But, as shown earlier both the state and local governments have a basis for accessing the debt market to finance their deficits and other spending.

In order to increase investors, confidence, the government's strategy for local government bonds should be introduced and special assistance provided for the development of the municipal bond market. Special assistance should include government guarantee against default or a special credit guarantee scheme similar to the system available in the US for municipal bonds.

\section{Ability to Trade Securities}

A viable municipal bond market should also provide for the liquidity of the bonds. This would mean an active secondary market where investors can dispose their holdings easily and cheaply. The infrastructure for trading in Malaysian Government Securities (MGS) already exists and it is only a matter of extending the market to include municipal bonds for trading purposes. Various components of market infrastructure are already in place such as Fully Automated System for Tendering (FAST), Bond Information and Dissemination System (BIDS), Electronic Transfer System for Funds and Securities (SPEEDS) (World Bank, 1995)

The secondary market for MGS is shown in Table 4. In 1998, RM42,506 million securities of MGS and Cagamas were traded in the secondary market. 3.7 times more of the RM11,453 million traded in 1989.

Table 4

Secondary Market Trading Volume, 1987-1998 (RM million)

\begin{tabular}{|c|c|c|c|}
\hline Year & $\begin{array}{c}\text { Malaysian Government } \\
\text { Securities }\end{array}$ & $\begin{array}{c}\text { Cagamas Debt } \\
\text { Securities }\end{array}$ & Total \\
\hline 1989 & 5,750 & 5,703 & 11,453 \\
1990 & 6,818 & 5,665 & 12,483 \\
1991 & 7,699 & 66 & 7,765 \\
1992 & 5,467 & 1,301 & 6,768 \\
\hline
\end{tabular}


(continued)

\begin{tabular}{|c|c|c|c|}
\hline Year & $\begin{array}{c}\text { Malaysian Government } \\
\text { Securities }\end{array}$ & $\begin{array}{c}\text { Cagamas Debt } \\
\text { Securities }\end{array}$ & Total \\
\hline 1993 & 18,808 & 3,854 & 22,662 \\
1994 & 10,887 & 8,604 & 19,491 \\
1995 & 3,846 & 16,159 & 20,005 \\
1996 & 25,374 & 4,177 & 29,551 \\
1997 & 12,367 & 15,230 & 27,597 \\
1998 & 27,326 & 15,180 & 42,506 \\
\hline
\end{tabular}

Source: Bank Negara Malaysia (1989), (1995), (1998). Annual Report

\section{Government Assistance}

To help develop the market, the government can directly facilitate purchases of municipal bonds by institutional investors as is currently being done for MGS. Selected institutional investors such as the Employees Provident Fund (EPF), Tabung Haji, Lembaga Tabung Angkatan Tentera (LTAT), financial institutions as well as insurance companies can be regulated to buy municipal bonds $(\mathrm{Ng}$ Beoy Kui, 1989). In order to make the municipal bonds attractive, the holdings of these bonds should be counted as satisfying the minimum liquidity or investment requirement. A window for selling a limited amount of municipal bonds can be opened at the central bank to encourage institutional holdings of municipal bonds.

Other government assistance can include tax exemption, i.e. interest on municipal bonds is not subject to income tax. Through this as well as other measures, a viable market for municipal bonds can be developed.

\section{Acceptable Return on Investment}

Giving incentives to increase the return on investment would go a long way towards the development of a municipal bond market. Exemption from taxation of the municipal bond interest income may be the principal reason why a large, active municipal market exists in the U.S., as suggested by the World Bank. In addition, Malaysia has also given exemption on stamp duty for all non- government bonds issued since 1989. With effect from 1993, the exemption on interest income earned by individuals from non-convertible bonds issued by listed companies was also extended to include those issued by unlisted companies but rated by Rating Agency Malaysia (RAM) (Bank Negara Malaysia, 1994).

The rate of return on government securities until 1987 was administered by the government and thus, has been relatively lower than other comparable investments. This is understandable since there is no credit risk attached to holding government bonds. The rates while infrequently adjusted, have, over the years, indicated a slowly increasing trend (Thillainathan, 1996). Coupon rates paid on corporate bonds have generally been higher than the rates for government bonds, which reflect the higher risks associated. Hence, any opportunity that would increase the return on investment would encourage investors to purchase municipal bonds (Affifudin Omar, 2001).

\section{Credit Quality: Tax Supported Debtor Revenue- Backed Debt}

In Malaysia general obligations on borrowings are seen to be problematic because many local governments typically do not have sufficient tax revenues to pay back significant levels of debt. Taxation is a federal government function. Federal and state grants typically account for most of the local government revenues. Nevertheless, for big 
municipals such as the MCPJ, KLCH, MCPI there might be a possibility to borrow private capital as they appear to be able to generate their own revenue (MCPJ, 2000; KLCH,1998; MCPI, 1995).

In order to sell revenue bonds, local governments would therefore be facing the challenge of revenue deficiency. Investors who are familiar with municipal utility services are aware that such services are almost never profitable. Therefore if a bond is to finance such services, it would need more security than projected revenues in order to attract investors at affordable interest rates. This is where incentives like an insurancelinked credit guarantee scheme would be helpful to municipal bond issues.

\section{Information Regarding Risks}

Malaysia is in the midst of improving the standards for disclosure, auditing, accounting, or financial reporting. Full transparency is important for bonds, because investors need information to confirm the willingness and ability of issuers to generate future project revenues necessary to pay off the debts.

Two rating agencies, the Rating Agency Malaysia Berhad (RAM) and Malaysia Rating Corporation Berhad (MARC) were established to provide professional assistance to investors in processing complex information for their investment decisions. RAM was established in 1990 while MARC, in 1995. Being local, RAM and MARC have the advantage of being more familiar with the Malaysian economy, local politics and corporate cultures than foreign rating agencies. These two rating agencies have a technical relationship with international rating agencies that is RAM with Duff and Phelps Credit Rating Co. (DCR), and MARC with Thomson Bank Watch. As of the end of August 1998, RAM had rated 428 private debt securities issues valued at RM68.27 billion (Rajandran, 2001).

With regard to the rating agencies, questions sometimes linger about their independence from government influence. Hence, in order to ensure its independence and objectivity, RAM was established as a private limited company with no ownership by the government. It has ownership participation from 51 financial institutions with no single shareholder holding of more than 4.9 percent equity interest. Meanwhile, MARC is owned by the stock-brokerage companies, insurance companies and discount houses (Rajandran, 2001).

As of 1994, RAM went a step further by encouraging all banks, merchant banks and finance companies to be rated as well. If a nonrated financial institution provides a bank guarantee for a proposed bond issue, the bond will have to rely on the issuer's stand-alone rating.

\section{Attracting a Supply of Municipal Bond}

\section{Borrowing Costs}

Although a low interest rates environment provides cheaper cost for financing by issuing bonds for companies, the cost of issuing bonds remains relatively high. This cost includes a long list of fees to be paid: financial and legal fees, underwriting fees, rating fees, trustee fees and other fees. All these fees add up to making the primary issues rather unattractive. Besides, trading costs are also high. Corporate bond trading on the Kuala Lumpur Stock Exchange (KLSE) attracts a commission of 1 percent of the transacted price, payable by both buyer and seller (transaction cost involved in trading of government bond attracts only a brokerage fee of 0.015 percent). The high cost of trading in bonds affects its liquidity and marketability. The high transaction cost of issuing and trading has contributed to the slow development of corporate bonds until recent years. In addition, the entire issuance process is rather lengthy; the actual experience reflected periods averaging between 8-9 months.

A variety of methods have been explored and used in Malaysia to reduce the issuance costs. One of them is direct placements of the debts with investors, rather than the competitive public offering. This method can eliminate underwriting costs and reduce costs associated with information disclosure, particularly if the bonds are not listed on the security exchange. Direct placement can promote market development by building successful borrowing track records for new kinds of securities, such as municipal bonds. But, it 
Table 5

Cost Structure of a Ringgit Corporate Bond Issue

Rating fees

Surveillance fee (annually)

$0.03 \%$

Management, underwriting and placement fees

$1 \%-2 \%$

Source: Bank Negara Malaysia (1989). Annual Report

involves developmental costs. Direct placements are likely to be less transparent, do much less in terms of promoting investor understanding of a new type of security, and may diminish the ability of investors to trade the bonds.

\section{Long Term Debt}

Bonds that have long maturities are very rare in Malaysia particularly those issued by corporations. This is because investors are uncertain of the willingness and ability of the issuers to make timely debt service payment over a long period. Investors generally prefer maturities of a shorter period that is five to ten years as opposed to ten to twenty years. For example, the longest maturities for Cagamas bonds are seven years. Most Cagamas bonds have a term of only three years (Bank Negara Malaysia, 1989 \& 1998). The concentration of liquidity in short-term bonds is detrimental to the long-term bond markets. An illiquid long-term bond market leads to the distortion in the government yield curve as the government yields cannot act as a good benchmark.

Malaysia has adopted several programs for deepening its long-term financial markets and extracting the benchmark for the long-term bond yields. However, the programs were derailed by the Asian crisis of 1997, which increased demand for short-term rather than long-term securities. Therefore, Malaysia has still to be content with illiquid long-term bond markets.

One of the significant programs to establish a good benchmark yield curve in Malaysia is the introduction of the Khazanah bonds in the year 1997. However, the issuance of Khazanah bonds also concentrated over short maturities (Bank Negara Malaysia, 1994).

\section{Formal Oversight}

An active role by the government and monetary authority is required if a municipal bond market is to develop. The supply function is already there - the number of local government authorities and public utilities that need funds to finance capital and other expenditure. Bringing the issuers to the market is the big issue and it is here that governmental assistance is crucial.

\section{CONCLUSION}

It is apparent that the basic market strength needed to introduce municipal bonds is more or less in place. However, as municipal bonds are still untested, there are many precautions and processes that need to be taken to further verify the viability of such a bond market in Malaysia. Among others, improving local government revenue base as well as the institutional framework within which municipal services are delivered requires attention. In other words, to establish the municipal bond market, the government will have to help stabilize local government revenues, so that municipal officials and potential lenders alike can make realistic assessments about the future capacity of the local government to repay debts. The municipal financial statements need to be standardized. Local authorities need to acquire the capacity to prepare capital budgets and evaluate long-term financing plans. Practical arrangements for strengthening the security behind municipal borrowings need to be put in place. Once all the conditions are met, the private sector lending to the local governments can grow. 
All sectors must be aware that there are advantages to the emergence of a municipal bond market that could lead to higher funds available for carrying out municipality work. In Malaysia, there are a few municipals with a proven track record and ready to issue bonds, thus providing a strong base for the faith of a Malaysian municipal bond market.

\section{REFERENCES}

Affifudin Omar. (2001). Keynote address. Seminar on Ringgit Bond Market Thrust: Institutional Investor's Role and Perspectives, Employees Provident Fund, Securities Commission.

Bank Negara Malaysia (1989). Annual Report. Kuala Lumpur: Bank Negara Malaysia

(1991). Annual Report. Kuala Lumpur: Bank Negara Malaysia

(1994). Annual Report. Kuala Lumpur: Bank Negara Malaysia

(1995). Annual Report. Kuala Lumpur: Bank Negara Malaysia

(1998). Annual Report. Kuala Lumpur: Bank Negara Malaysia

(2001). Annual Report. Kuala Lumpur: Bank Negara Malaysia

(2002). Annual Report. Kuala Lumpur: Bank Negara Malaysia

Bland, R. L. (1985). The interest savings from optimizing size and frequency of participation in the municipal bond market. $P u b$ lic Budgeting and Finance, 4 (Winter), 5359.

Cook, T. Q. (1982). Determinants of individual tax-exempt bond yields: A survey of the evidence. Federal Reserve Bank of Richmond Economic Review (May/June), 1439.
Cuciti, P. (1991). Infrastructure and the economy: serious debate in the profession. Municipal Finance Journal, 12 (4), 73-81.

Fatimah Wati Ibrahim \& Mohd Faisol Md. Salleh (2002). Efficiency analysis of local governments in Malaysia. Seminar School of Economics Universiti Utara Malaysia.

Fortune, P. (1992). The municipal bond market, part II: problems and policies. New England Economic Review, (May/June), 47 65.

Hildreth, W. B. (1993). State and local governments as borrowers: strategic choices. Public Administrative Review, 53 (1), 41-49.

Jun, Peng, \& Brucato P. F. Jr. (2003). Another look at the effect of method of sale on the interest cost in the municipal bond market - A certification model. Public Budgeting \& Finance. 23 (1), 73-95.

Kuala Lumpur City Hall (1998). Annual Report. $\mathrm{KLCH}$.

Municipal Council of Penang Island (1995). Annual Report. MCPI.

Municipal Council of Petaling Jaya (2000). Annual Report. MCPJ.

Miller, G. J. (1993). Debt management networks. Public Administration Review. 53 (1), 50 $-58$.

$\mathrm{Ng}$ Beoy Kui (1989). The Development of Capital Markets in The SEACEN countries. The SEACEN Centre.

Petersen, J. \& Crihfield, J. B. (2000). Linkages between local governments and financial markets: a tool kit to developing subsovereign credit markets in emerging economies. Municipal Finance, Background Series 1, World Bank. 
Rajandran, C. (2001). Use of ratings as an investor's tool and in-house development of credit analytical capabilities. Seminar on Ringgit Bond Market Thrust: Institutional Investor's Role and Perspectives, Employees Provident Fund, Securities Commission.

Thillainathan, R. (1996). Malaysia's Bond Market: The Further Reforms Required to Escape Under-development. Institute of Strategic and International Studies (ISIS) Malaysia.
Sharp, E. B. (1986). The politics and economics of the New City debt. American Political Science Review, 80 (4), 1271-1288.

World Bank (1995). The Emerging Asian Bond Market: Malaysia. World Bank Report.

Ziebell, M. T. \& Rivers, M. J. (1992). The decision to rate or not to rate: The case of municipal bonds. Journal of Economics and Business, 44 (4), 301 - 316. 